НАУКОВИЙ ВІСНИК

Scientific messenger of Lviv National University of
Veterimary Medicicie and Biotechnologies

(5)

RIES: VETERINARY SCIEN
Науковий вісник Дьвівського національного університету ветеринарної медицини та біотехнологій імені С.3. Гжицького. Серія: Ветеринарні науки

Scientific Messenger of Lviv National University of Veterinary Medicine and Biotechnologies. Series: Veterinary sciences

UDC 619: 616.5 - 002.828:615.03

\title{
Comparative characteristics of different methods of treatment of microsporia
}

\author{
Y. V. Martyniv, Ya. V. Kisera \\ Stepan Gzhytskyi National University of Veterinary Medicine and Biotechnologies Lviv, Ukraine
}

Article info

Received 20.09.2021

Received in revised form 21.10.2021

Accepted 22.10.2021

Stepan Gzhytskyi National University of Veterinary Medicine and Biotechnologies Lviv, Pekarska Str., 50, Lviv, 79010, Ukraine. Tel.: +38-097-155-47-53 E-mail:julia_yush@ukr.net
Martyniv, Y. V., \& Kisera, Ya. V. (2021). Comparative characteristics of different methods of treatment of microsporia. Scientific Messenger of Lviv National University of Veterinary Medicine and Biotechnologies. Series: Veterinary sciences, 23(104), 47-54. doi: 10.32718/nvlvet10408

Microsporia is the most common disease of fungal etiology, most often caused by the pathogen Microsporum canis. Treatment of this disease requires a comprehensive approach, because the disease is dangerous to humans. Therefore, in the treatment of microspores, it is important not only to carry out therapeutic measures, but also to prevent the spread of the pathogen of the fungus in the environment and increase the immune status of the organism in the fight against infection. The main source of infection is cats. In order to determine the effectiveness of treatment of microsporia by various methods, studied of the blood and skin of guinea pigs infected with the pathogen M. canis. Sick animals were divided into three groups. The first group was treated with the systemic antifungal itraconazole and topical treatment with a solution of clotrimazole. Treatment of the second group was performed with a topical antifungal agent (1\% solution of clotrimazole) with vaccination with the antifungal vaccine "Vakderm". For the third group, the developed drugs were used - antifungal agent "Micromar" and immunostimulant "Biogluk". During treatment, hematological and immunological blood researches and histological skin examinations were performed. During treatment with antifungal drugs (itraconazole and clotrimazole) the number of leukocytes decreases from $11.13 \pm 0.72$ to $7.13 \pm 0.22$, rod-shaped neutrophils from $15.76 \pm 1.29$ to $5.50 \pm$ 0.76 , and segmental increases from $12.17 \pm 1.47$ to $24.17 \pm 2.27$, decreases ESR from $5.67 \pm 0.67$ to $2.33 \pm$ 0.42, which occurs when inhibiting the inflammatory response of the organism to infection. Thrombocytopenia (from $231.17 \pm 7.60$ to $184.33 \pm 7.65$ ) and eosinophilia (from $2.70 \pm 0.73$ to $7.33 \pm 1.33$ ) are also noted. There is a slight increase in T-helpers and a decrease in T-suppressors. Histologically, the infiltration of the dermis by histiocytes and eosinophils under skin persists. In the treatment of microsporia by treatment with $1 \%$ solution of clotrimazole and vaccination with the vaccine "Vakderm" the results of studies showed that the number of leukocytes decreases from $11.13 \pm 0.72$ to $5.35 \pm 0.31(P<0.01)$, rodshaped neutrophils from $15.76 \pm 1.29$ to $7.67 \pm 0.56$, and segmental increases from $12.17 \pm 1.47$ to $22.17 \pm$ 0.91 ( $P<0.001)$, decreases). The number of T-helpers is increasing. The histological picture on day 7 is characterized by hyperkeratosis, and on day 14 the hyperemia of the basal layer of the epidermis persists. When using the antifungal drug "Micromar" and immunostimulant "Biogluk" the results of studies showed that the number of leukocytes decreases from $11.13 \pm 0.72$ to $6.95 \pm 0.10$, rod-shaped neutrophils from $15.76 \pm 1.29$ to $6.17 \pm 0.65$, and segmental increases from $12.17 \pm 1.47$ to $22.00 \pm 0.86$, decreases ESR from $5.67 \pm 0.67$ to $2.17 \pm 0.31$. Increases the number of T-helpers and the number of natural killers and Tsuppressors is gradually decreasing. Histological changes are presented in the form of dilation of blood vessels and visualization of single erythrocytes in the dermis on day 14 of treatment.

Key words: microsporia, leukocytes, lymphocytes, infiltration, dermis, guinea pigs, clotrimazole, itraconazole.

\section{Порівняльна характеристика різних методів лікування мікроспорії}

\author{
Ю. В. Мартинів, Я. В. Кісера
}

Львівський національний університет ветеринарної медицини та біотехнологій імені С. 3. Гжицького, м. Львів, Україна 
Мікроспорія є найбільш поширеним захворюванням грибкової етіології, щуо найчастіше викликається збудником Містоврогит canis. Лікування даного захворювання потребує комплексного підходу, оскільки хвороба є небезпечною і для людини. Тому при лікуванні мікроспорії важливо не лише провести терапевтичні заходи, а й запобігти розповсюдженню збудника спор гриба в навколишньому середовищі та підвищити імунний статус огранізму в боротьбі з інфекцією. Основним джерелом зараження є коти. 3 метою з'ясування ефективності лікування мікроспорії різними методами проведені дослідження крові та шкіри мурчаків, інфікованих збудником Місrоsротит сапіs. Хворих тварин поділили на три групи. Першій групі проводили лікування системним антимікотиком ітраконазолом та місцеві обробки розчином клотримазолу. Лікування другої групи проводилося протигрибковим засобом місиевої дї (1% розчин клотримазолу) з проведенням вакцинації протигрибковою вакциною “Вакдерм”. Для третьої групи застосовували розроблені препарати - протигрибковий засіб “Мікромар” та імуностимулятор “Біоглюк”. В період лікування проводилися гематологічні й імунологічні дослідження крові та гістологічні дослідження шкіри. При лікуванні протигрибковими препаратами (ітраконазол і клотримазол) кількість лейкочитів знижується з 11,13 \pm 0,72 до 7,13 \pm 0,22, паличкоядерних нейтрофілів 3

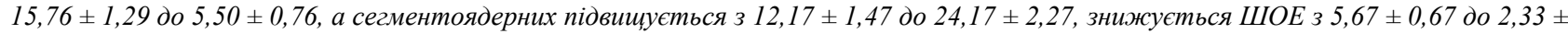
0,42, щзо виникає при гальмуванні запальної реакиії організму на інфекцію. Також спостерігається тромбоцитопенія (з $231,17 \pm$

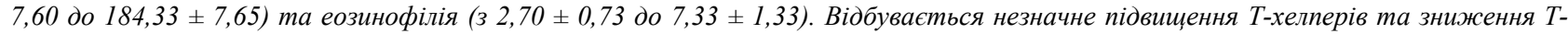
супресорів. Гістологічно зберігається інфільтрачія в дермі гістіочитами та поодонокими еозинофілами. При лікуванні мікроспорії обробками 1 \% розчином клотримазолу та проведенням вакцинації вакциною “Вакдерм” отримані результати досліджень засвідчили, щьо кількість лейкочитів знижується з $11,13 \pm 0,72$ до 5,35 0,31 (P<0,01), паличкоядерних нейтрофілів з $15,76 \pm 1,29$ до

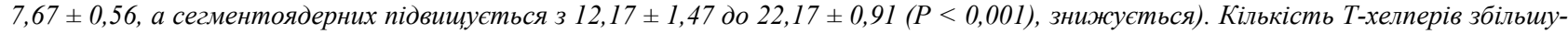
ється. Гістологічна картина на 7 день характеризується гіперкератозом, а на 14 добу зберігається гіперемія базального шару епідермісу. При використанні протигрибкового препарату “Мікромар” та імуностимулятора “Біоглюк” результати досліджень

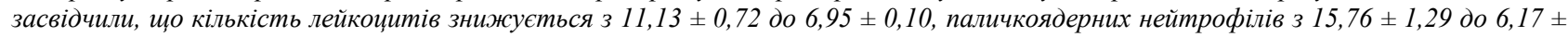

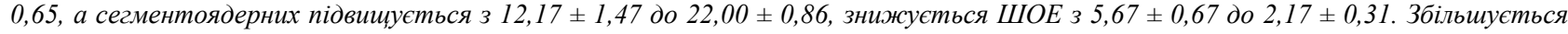
кількість Т-хелперів та поступово знижується кількість натуральних кілерів та Т-супресорів. Гістологічні зміни представлені у вигляді розширення кровоносних судин та візуалізацією поодиноких еритроцитів в товщі дерми на 14 день лікування.

Ключові слова: мікроспорія, лейкочити, лімфоцити, інфільтрачія, дерма, мурчаки, клотримазол, ітраконазол.

\section{Вступ}

Дерматофітози набувають все ширшого розповсюдження, одним із яких є мікроспорія (Pototskyi, 2000). Мікроспорія - високонтагіозне захворювання, спільне для людей і тварин (Bezlushhenko, 2017). Лікування мікроспорії потребує комплексного підходу з використанням системних та місцевих антимікотиків. Встановлено залежність мікроспорії від імунного статусу організму (de Hoog et al., 2000). Найчастіше при мікроспорії використовують препарати групи азолів, до яких належать клотримазол та інтраконазол. Ця група препаратів характеризується малотоксичністю, при їхньому використанні рідко виникає резистентність у збудників дерматомікозів (Medvedeva et al., 2002).

Джерелом небезпеки зараження у людини є коти $(80,5 \%)$, особливо котенята (70-80\%), рідше собаки. Вони є резервуаром збудника в навколишньому середовищі (Novoselov \& Novoselov, 2004). Порушення зоогігієнічних правил утримання та годівлі тварин сприяє поширенню мікроспорії.

Для досягнення якісного лікування мікроспорії до терапії повинен бути комплексний підхід, оскільки перебіг мікроспорії часто ускладнюється вторинною мікрофлорою, а імунна резистентність впливає на тривалість перебігу хвороби (Medvedeva et al., 2007). Важливим фактором при лікуванні мікроспорії є тривалість курсу лікування, його ефективність та вартість (Sergeev, 2003).

3 метою з'ясування ефективності лікування мікроспорії препаратами “Мікромар" (Kisera et al., 2020a) i “Біоглюк” (Kisera et al., 2020b) були проведені дослідження на заражених мікроспорією мурчаках. За перебігу хвороби проводилися морфологічні дослідження крові та визначення вмісту Т- і В-лімфоцитів і їх субпопуляцій, гістологічні дослідження шкіри під час лікування та на стадії одужання.
Хворих тварин було поділено на 3 групи по 6 голів. Перша група отримувала терапію системним протигрибковим препаратом ітраконазол в дозі 510 мг/кг кожні 24 години протягом 21 дня (Gupta et al., 1997; Ramsey, 2007). Препарат задавали перорально. Також на ділянки ураження проводили місцеві обробки $1 \%$ розчином клотримазолу 1 раз на добу 21 день. Другій групі проводили місцеві обробки протигрибковим засобом (1 \% розчин клотримазолу) та вакцинацію протигрибковою вакциною "Вакдерм" 2разово 3 інтервалом 10-14 діб (Kisera et al., 2020). Третій групі наносили препарат "Мікромар" на уражені ділянки шкіри 1 раз на день місцево протягом 21 дня та випоювали 1 раз на день препарат “Біоглюк” 21 день. Первинно були проведені забори крові у здорових тварин та у хворих на 21 та 42 день після зараження. Під час лікування проводили дослідження крові на 7, 14 та 21 день та біопсію шкіри на 7 та 14 день після початку застосування препаратів.

Мета $і$ завдання дослідження. Провести гематологічні й імунологічні дослідження крові та гістологічні дослідження шкіри при лікуванні мікроспорії у мурчаків різними методами.

\section{Матеріал і методи досліджень}

Дослідження проводились в умовах віварію Тернопільського національного медичного університету імені І. Я. Горбачевського. Гематологічні та імунологічні дослідження крові проводили в лабораторії шпиталю імені Митрополита Андрея Шептицького міста Львова. Гістологічні дослідження проводили у лабораторії клініко-біологічних досліджень ДНДКІ ветпрепаратів та кормових добавок міста Львова.

Кількість еритроцитів і лейкоцитів визначали шляхом підрахунку в камері Горяєва, вміст гемоглобіну - геміглобінціанідним методом. 
Лейкограму виводили на основі підрахунку та диференціації 200 клітин лейкоцитів у мазках крові, пофарбованих за методикою Романовського-Гімзи. При цьому враховувався розмір клітин, величина і форма ядра, наявність та колір зерен у цитоплазмі. Гематокритну величину визначали за допомогою гематокритних капілярів шляхом центрифугування у спеціальній центрифузі (10 хвилин при 3000 обертів за хвилину), швидкість осідання еритроцитів (протягом 1 години) - 3 допомогою піпеток Панченкова (Vlizlo et al., 2014).

Підрахунок Т- і В-лімфоцитів проводили 3 допомогою еритроцитарного діагностикуму ТЗОВ “Лабораторія Гранум” м. Харкова. Метод грунтується на визначенні субпопуляцій Т- і В-лімфоцитів за допомогою реакції розеткоутворення з еритроцитами, на яких адсорбовані моноклональні антитіла проти рецепторів СД3 (Т-лімфоцити), СД4 (Т-хелпери), СД8 (Т-супресори), СД19 або СД22 (В-лімфоцити), СД16 (натуральні кілери). Облік результатів дослідження проводився у світловому мікроскопі 3 імерсійною системою.

Цифровий матеріал статистично обробляли за допомогою комп'ютерної програми Excel 3 пакету “Microsoft Office 2007”. Вірогідність визначали за tкритерієм.

Матеріал для гістологічного дослідження (шматочки шкіри) фіксували в 10-12 \% охолодженому розчині нейтрального формаліну з подальшим заливанням у парафін за схемою, запропонованою Г. А. Меркуловим (Merkulov, 1969; Horalskyi et al., 2005). Зафіксовані шматочки товщиною 2 мм промивали у воді 30 хв і більше, після чого підсушували на фільтрувальному папері та проводили через спирти
(75, 96 i $100^{\circ}$ для зневоднення і знежирення - добу в кожному із спиртів). Потім просочували розчинником парафіну ксилолом 1,5 год. 3 ксилолу шматочки переносили у насичений розчин парафіну у ксилолі на 1,5 год при температурі $37^{\circ} \mathrm{C}$. Потім шматочки витримували у розплавленому парафіні при температурі 54-55 ${ }^{\circ} \mathrm{C}$, тобто при температурі на $2-3{ }^{\circ} \mathrm{C}$ вищій, ніж температура плавлення парафіну, до 2 годин у першій порції парафіну і до 2 годин у другій. Після чого їх переносили у порцелянові чашки й заливали розплавленим парафіном $з$ подальшим швидким охолодженням у холодильній камері. Після затвердіння парафіну шматочки нарізали 3 парафіном і наклеювали на дерев'яні кубики. Гістозрізи товщиною 5-7 мкм виготовляли на санному мікротомі МС-2. Для морфологічної оцінки клітин і тканин застосовували фарбування гематоксиліном та еозином. Мікроскопію проводили 3 допомогою мікроскопа OLIMPUS CX-41.

Експеримент відповідає правилам ARRIVE. Проводився згідно із Законом про тварин у Великобританії (Наукові процедури) 1986 року та відповідними вказівками.

\section{Результати та їх обговорення}

Отримані результати засвідчили (табл. 1), що при лікуванні мікроспорії ітраконазолом та клотримазолом відбулося гальмування запальної реакції організму, на що вказує зниження кількості лейкоцитів 3 $11,13 \pm 0,72$ до 7,13 $\pm 0,22(\mathrm{P}<0,01)$, паличкоядерних нейтрофілів $315,76 \pm 1,29$ до 5,50 $\pm 0,76(\mathrm{P}<0,001)$, а зростання сегментоядерних з $12,17 \pm 1,47$ до 24,17 \pm $2,27(\mathrm{P}<0,001)$, знижується ШОЕ $35,67 \pm 0,67$ до $2,33 \pm 0,42$ (при $\mathrm{P}<0,01)$.

\section{Таблиця 1}

Морфологічні показники крові у мурчаків при лікуванні мікроспорії ітраконазолом та клотримазолом (M \pm m, $\mathrm{n}=6$ )

\begin{tabular}{|c|c|c|c|c|c|c|}
\hline \multirow{2}{*}{\multicolumn{2}{|c|}{ Показники }} & \multirow{2}{*}{$\begin{array}{l}\text { Одиниці } \\
\text { виміру }\end{array}$} & \multirow{2}{*}{$\begin{array}{c}\text { Хворі на } \\
42 \text { день }\end{array}$} & \multicolumn{3}{|c|}{ Лікування } \\
\hline & & & & 7 днів & 14 днів & 21 день \\
\hline Гематокритна & Іина & $\%$ & $37,17 \pm 7,60$ & $36,83 \pm 1,64$ & $36,67 \pm 0,95$ & $36,07 \pm 0,80$ \\
\hline Гемогло & & г/л & $113,33 \pm 4,51$ & $118,83 \pm 2,32$ & $120,00 \pm 1,51$ & $118,17 \pm 3,04$ \\
\hline Еритроц & & $\mathrm{T} /$ л & $5,25 \pm 0,21$ & $5,72 \pm 0,14$ & $5,77 \pm 0,09$ & $5,77 \pm 0,17$ \\
\hline Тромбоц & & Г/л & $231,17 \pm 7,60$ & $183,17 \pm 6,22 * *$ & $166,00 \pm 5,69 * * *$ & $184,33 \pm 7,65^{* *}$ \\
\hline Лейкоц & & Г/л & $11,13 \pm 0,72$ & $8,08 \pm 0,52$ & $7,05 \pm 0,23 * *$ & $7,13 \pm 0,22 * *$ \\
\hline \multirow{2}{*}{ Нейтрофіли } & $\Pi$ & $\%$ & $15,76 \pm 1,29$ & $8,67 \pm 0,88 * *$ & $7,10 \pm 0,70 * * *$ & $5,50 \pm 0,76^{* * *}$ \\
\hline & $\mathrm{C}$ & $\%$ & $12,17 \pm 1,47$ & $25,17 \pm 1,87 * * *$ & $19,90 \pm 1,78 * * *$ & $24,17 \pm 2,27 * * *$ \\
\hline Еозиноф & & $\%$ & $2,70 \pm 0,73$ & $9,0 \pm 0,73 * * *$ & $10,80 \pm 0,79 * * *$ & $7,33 \pm 1,33 * * *$ \\
\hline Базофі. & & $\%$ & 0 & 0 & 0 & 0 \\
\hline Моноци & & $\%$ & $4,10 \pm 0,83$ & $3,33 \pm 0,49$ & $3,70 \pm 0,26$ & $3,83 \pm 0,54$ \\
\hline Лімфоц & & $\%$ & $65,20 \pm 1,48$ & $53,83 \pm 1,30$ & $58,50 \pm 2,53$ & $59,17 \pm 1,33$ \\
\hline ШОВ & & мм/год & $5,67 \pm 0,67$ & $2,83 \pm 0,31 * *$ & $2,83 \pm 0,31 * *$ & $2,33 \pm 0,42 * *$ \\
\hline Кольоровий I & ник & & $0,76 \pm 0,02$ & $0,76 \pm 0,01$ & $0,76 \pm 0,01$ & $0,76 \pm 0,01$ \\
\hline
\end{tabular}

Примітка: вірогідність різниць 3 хворими тваринами: ** - при $\mathrm{P}<0,01 ; * * *-$ при $\mathrm{P}<0,001$

Також виявлено тромбоцитопенію (з 231,17 $\pm 7,6$ до $184,33 \pm 7,65)$ та еозинофілію (з 2,70 $\pm 0,73$ до $7,33 \pm 1,33)$. Причиною тромбоцитопенії найчастіше $\epsilon$ алергічні реакції. Еозинофіли в крові збільшуються за умови сенсибілізації організму алергеном. Вони залучаються до реакції гіперчутливості негайного та упо- вільненого типу (Рopov et al., 2004). Еозинофілія $\epsilon$ ознакою перебігу алергічної реакції, спричиненою алергеном. Беручи до уваги однакові умови утримання та годівлі дослідних груп тварин, а також присутність клотримазолу в усіх методах лікування, можна припустити, що ітраконазол може провокувати вини- 
кнення явища алергізації організму. В процесі лікування виявлено незначне підвищення Т-хелперів та зниження Т-супресорів (табл. 2) як наслідок нормалі- зації імунної відповіді організму (Kindt \& Osborne, 2006).

\section{Таблищя 2}

Імунологічні показники крові у мурчаків при лікуванні мікроспорії ітраконазолом та клотримазолом $(\mathrm{M} \pm \mathrm{m}$, $\mathrm{n}=6$ )

\begin{tabular}{cccccc}
\hline \multirow{2}{*}{ Показники } & Одиниці & Хворі на & \multicolumn{3}{c}{ Лікування } \\
\cline { 4 - 6 } & виміру & 42 день & 7 днів & 14 днів & 21 день \\
\hline В-лімфоцити & $\%$ & $22,33 \pm 0,95$ & $22,00 \pm 1,15$ & $21,17 \pm 1,31$ & $19,83 \pm 0,79$ \\
Т-лімфоцити & $\%$ & $53,83 \pm 0,85$ & $59,00 \pm 1,00$ & $53,33 \pm 1,31$ & $53,33 \pm 0,84$ \\
О-лімфоцити & $\%$ & $23,84 \pm 1,14$ & $19,00 \pm 1,36$ & $25,50 \pm 1,41$ & $26,84 \pm 0,70$ \\
Натуральні кілери & $\%$ & $19,33 \pm 0,84$ & $22,00 \pm 0,82$ & $19,00 \pm 0,58$ & $18,33 \pm 0,76$ \\
Т-хелпери & $\%$ & $33,33 \pm 0,71$ & $32,17 \pm 0,83$ & $37,00 \pm 0,73$ & $36,17 \pm 0,49$ \\
Т-супресори & $\%$ & $23,00 \pm 1,51$ & $20,83 \pm 0,70$ & $19,50 \pm 0,96$ & $19,33 \pm 0,49$ \\
\hline
\end{tabular}

Проведені гістологічні дослідження на 7 добу лікування (рис. 1) засвідчили помірну інфільтрацію в дермі та незначне розшарування колагенових волокон, що $\epsilon$ ознакою регенератних процесів у шкірі (Hamade, 2016). Розшарування колагенових волокон виникло внаслідок набряку дерми та ï ураження великою кількістю гістіоцитарних інфільтратів (Dekio et al., 2015).

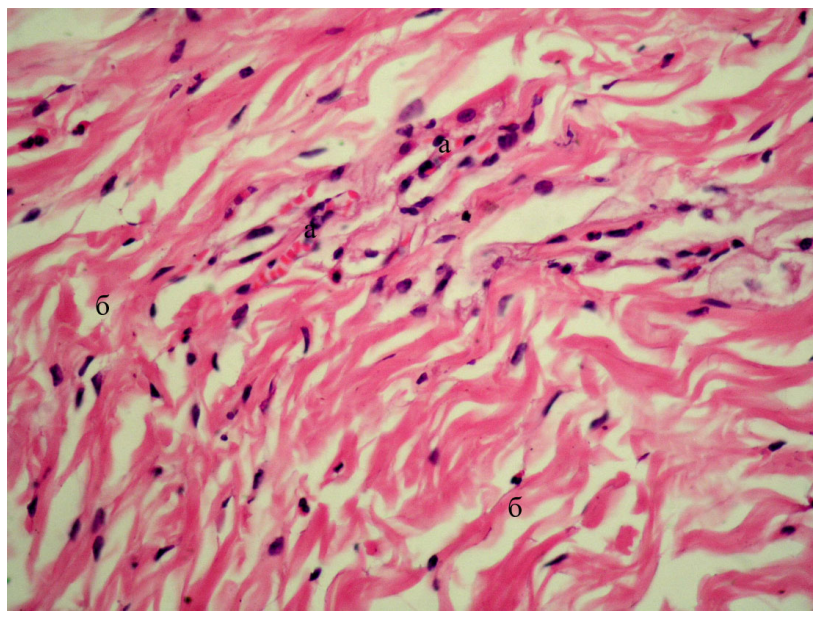

Рис. 1. Гістологічна структура шкіри мурчака на 7 день лікування: a - помірна лімфогістіоцитарна інфільтрація в дермі; б - незначне розшарування колагенових волокон. Гематоксилін та еозин. Ок. 10, об. 20

На 14 добу лікування зберігається інфільтрація дерми лімфогістіоцитарними компонентами 3 поодинокими еозинофілами, що вказує на перебіг запальної реакції (рис. 2). Причиною появи еозинофілів в інфільтраті $\epsilon$ ознакою прояву алергії, алергізації шкірного покриву та безпосереднього впливу алергена на організм (Vavilov et al., 2000). Функція еозинофілів в таких випадках полягає у нейтралізації гістаміну як медіатора запалення в місці локалізації запального вогнища (Colombo et al., 2012).

При лікуванні мікроспорії 1 \% розчином клотримазолу та вакциною "Вакдерм” отримані результати досліджень засвідчили, що кількість лейкоцитів знижується $311,13 \pm 0,72$ до 5,35 $\pm 0,31$ (Р <0,01), паличкоядерних нейтрофілів $315,76 \pm 1,29$ до 7,67 $\pm 0,56$ (P $<0,001)$, а сегментоядерних підвищується з 12,17 \pm
$1,47$ до $22,17 \pm 0,91$ ( $\mathrm{P}<0,001)$, знижується ШОЕ 3 $5,67 \pm 0,67$ до 2,83 $\pm 0,31$ (при $\mathrm{P}<0,01$ ) (табл. 3). Також виявлено незначне збільшення Т-хелперів та поступове зниження Т-супресорів (табл. 4), що свідчить про розвиток активної імунної відповіді на запалення інфекційної етіології (Peterson, 2008).

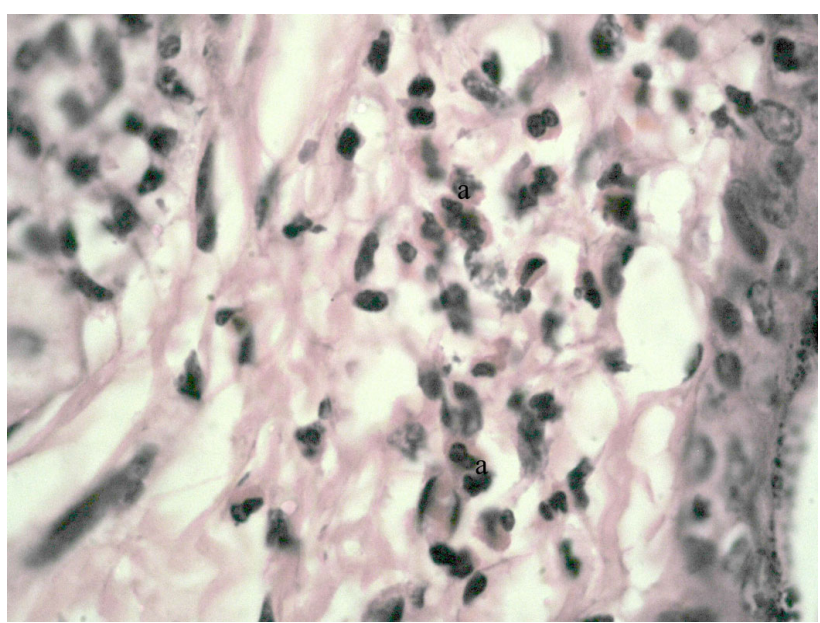

Рис. 2. Гістологічна структура шкіри мурчака на 14 день лікування: а - лімфогістіоцитарні інфільтрати в дермі. Гематоксилін та еозин. Ок. 10, об. 100

Гістологічними дослідженнями встановлено, що на 7 добу лікування роговий шар епідермісу потовщений (рис. 3). Виявлено ознаки лущення рогових клітин (Makurina, 2016). Ознаки гіперплазії базального шару відсутні. Дерма незначно потовщена. Ці зміни вказують на перебіг запальної реакції у верхніх шарах епідермісу (Scott et al., 2001). Проте встановлена чітка оконтурована пошаровість клітин епітелію, що $є$ ознакою регенеративних процесів у структурі шкіри (Vavilov et al., 2000).

На 14 добу лікування (рис. 4) спостерігається активна гіперемія базального шару епідермісу, але кровоносні судини в дермі без ознак застійної гіперемії (Cooke, 2012). Відсутня інфільтрація навколо волосяних цибулин. Поверхнева гіперемія $є$ ознакою перебігу місцевої запальної реакції (Kotsiumbas et al., 2014). 
Таблиця 3

Морфологічні показники крові у мурчаків при лікуванні мікроспорії 1 \% розчином клотримазолу та вакциною "Вакдерм" $(\mathrm{M} \pm \mathrm{m}, \mathrm{n}=6)$

\begin{tabular}{|c|c|c|c|c|c|c|}
\hline \multirow{2}{*}{\multicolumn{2}{|c|}{ Показники }} & \multirow{2}{*}{$\begin{array}{c}\text { Одиниці } \\
\text { виміру }\end{array}$} & \multirow{2}{*}{$\begin{array}{l}\text { Хворі на } \\
42 \text { день }\end{array}$} & \multicolumn{3}{|c|}{ Лікування } \\
\hline & & & & 7 днів & 14 днів & 21 день \\
\hline Гематокритна & ина & $\%$ & $37,17 \pm 7,60$ & $36,50 \pm 0,67$ & $36,67 \pm 0,56$ & $37,67 \pm 0,76$ \\
\hline Гемоглс & & г/л & $113,33 \pm 4,51$ & $113,50 \pm 2,62$ & $115,17 \pm 1,54$ & $113,83 \pm 3,66$ \\
\hline Еритроц & & $\mathrm{T} / л$ & $5,25 \pm 0,21$ & $5,38 \pm 0,16$ & $5,47 \pm 0,13$ & $5,63 \pm 0,10$ \\
\hline Тромбог & & Г/л & $231,17 \pm 7,60$ & $207,83 \pm 8,51^{*}$ & $222,33 \pm 6,59$ & $220,17 \pm 5,63$ \\
\hline Лейкоц & & Г/л & $11,13 \pm 0,72$ & $9,57 \pm 0,60$ & $8,20 \pm 0,50^{*}$ & $5,35 \pm 0,31 * *$ \\
\hline & $\Pi$ & $\%$ & $15,76 \pm 1,29$ & $24,00 \pm 0,73 * *$ & $10,83 \pm 0,60$ & $7,67 \pm 0,56^{*}$ \\
\hline Нейтрофіли & $\mathrm{C}$ & $\%$ & $12,17 \pm 1,47$ & $18,83 \pm 1,49 * *$ & $18,67 \pm 1,15^{* *}$ & $22,17 \pm 0,91 * * *$ \\
\hline Еозинод & & $\%$ & $2,70 \pm 0,73$ & $3,33 \pm 0,33$ & $3,17 \pm 0,48$ & $2,33 \pm 0,42$ \\
\hline Базофі & & $\%$ & 0 & 0 & 0 & 0 \\
\hline Моноц & & $\%$ & $4,10 \pm 0,83$ & $5,83 \pm 0,75$ & $6,00 \pm 0,73$ & $6,17 \pm 0,70$ \\
\hline Лімфоц & & $\%$ & $65,20 \pm 1,48$ & $58,00 \pm 1,18$ & $61,33 \pm 1,23$ & $61,67 \pm 1,09$ \\
\hline ШOF & & мм/год & $5,67 \pm 0,67$ & $4,67 \pm 0,33$ & $3,00 \pm 0,37^{*}$ & $2,83 \pm 0,31 * *$ \\
\hline Кольоровий 1 & Іик & & $0,76 \pm 0,02$ & $0,76 \pm 0,02$ & $0,77 \pm 0,01$ & $0,75 \pm 0,01$ \\
\hline
\end{tabular}

Примітка: вірогідність різниць з хворими тваринами: * - при $\mathrm{P}<0,05 ; * *-$ при $\mathrm{P}<0,01 ; * * *-$ при $\mathrm{P}<0,001$

\section{Таблиця 4}

Імунологічні показники крові у мурчаків при лікуванні мікроспорії 1 \% розчином клотримазолу та вакциною “Вакдерм" (M $\mathrm{m}, \mathrm{n}=6)$

\begin{tabular}{ccccc}
\hline \multirow{2}{*}{ Показники } & Одиниці & Хворі на & \multicolumn{2}{c}{ Лікування } \\
\cline { 3 - 5 } & виміру & 42 день & 7 днів & 14 днів \\
\hline В-лімфоцити & $\%$ & $22,33 \pm 0,95$ & $21,50 \pm 0,76$ & $20,83 \pm 0,60$ \\
Т-лімфоцити & $\%$ & $53,83 \pm 0,85$ & $59,00 \pm 1,00$ & $57,17 \pm 0,75$ \\
0-лімфоцити & $\%$ & $23,84 \pm 1,14$ & $19,50 \pm 0,87$ & $22,00 \pm 0,74$ \\
Натуральні кілери & $\%$ & $19,33 \pm 0,84$ & $20,67 \pm 0,88$ & $19,83 \pm 0,75$ \\
Т-хелпери & $\%$ & $33,33 \pm 0,71$ & $35,33 \pm 0,88$ & $36,67 \pm 0,88$ \\
Т-супресори & $\%$ & $23,00 \pm 1,51$ & $21,17 \pm 0,60$ & $19,67 \pm 0,67$ \\
\hline
\end{tabular}

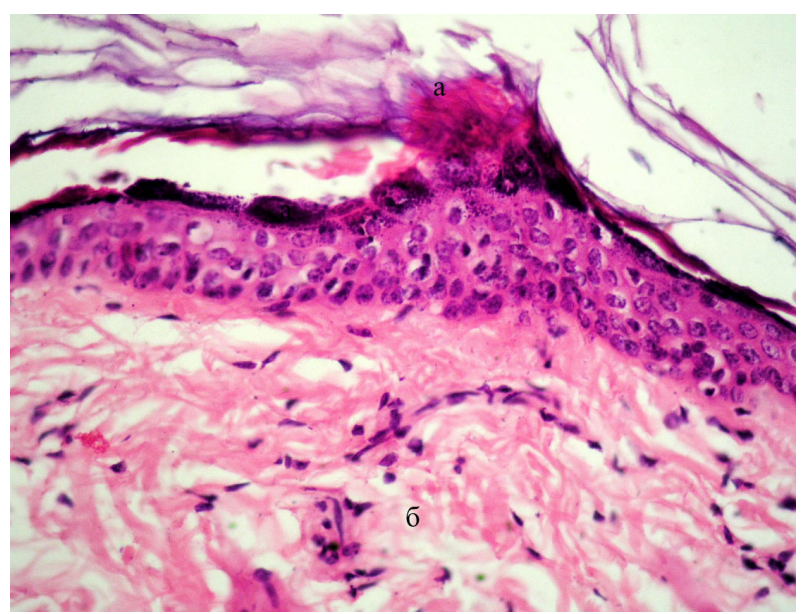

Рис. 3. Гістологічна структура шкіри мурчака на

7 добу лікування: а - потовщення рогового шару епідермісу; б - набряк дерми. Гематоксилін та еозин. Ок. 10 , об. 20

При лікуванні мікроспорії з використанням протигрибкового препарату "Мікромар" та імуностимулятора "Біоглюк” отримані результати досліджень засвідчили, що кількість лейкоцитів знижується 3 $11,13 \pm 0,72$ до $6,95 \pm 0,15(\mathrm{P}<0,01)$, паличкоядерних нейтрофілів з 15,76 $\pm 1,29$ до 6,17 $\pm 0,65$ (P $<0,001)$, а сегментоядерних підвищується з $12,17 \pm 1,47$ до 22,00 $\pm 0,86(\mathrm{P}<0,001)$, знижується ШОЕ з 5,67 $\pm 0,67$ до $2,17 \pm 0,31$ (при $\mathrm{P}<0,01$ ) (табл. 5).

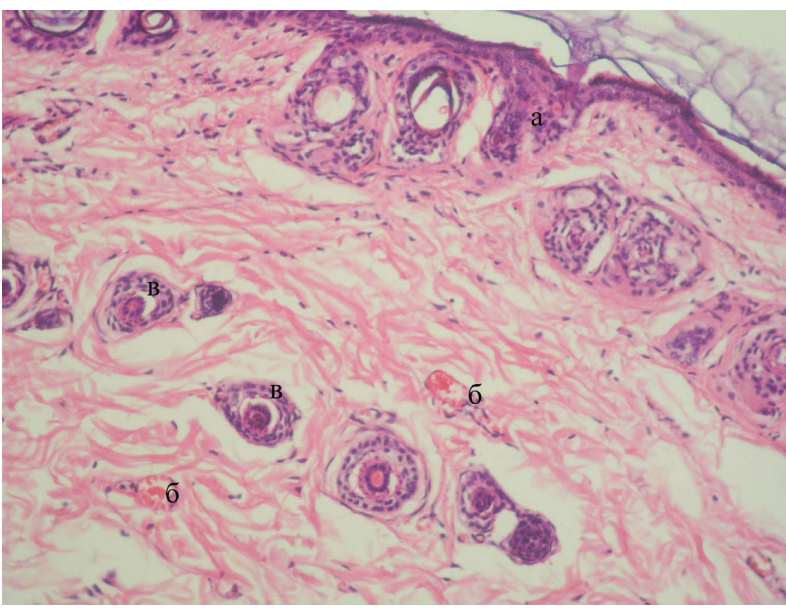

Рис. 4. Гістологічна структура шкіри мурчака на 14 добу лікування: а - активна гіперемія базального шару епідермісу; б - кровоносні судини в дермі; в- волосяні цибулини. Гематоксилін та еозин. Ок. 10, об. 10

Виявлено незначне збільшення Т-хелперів, що вказує на розвиток активної імунної відповіді при запаленні інфекційної етіології (табл. 6). Спостерігається поступове зменшення натуральних кілерів та Тсупресорів, що є ознакою підвищення опірності імунної системи (Kokhan, 1994). 
Таблиця 5

Морфологічні показники крові у мурчаків при лікуванні мікроспорії препаратами “Мікромар" та "Біоглюк” $(\mathrm{M} \pm \mathrm{m}, \mathrm{n}=6)$

\begin{tabular}{|c|c|c|c|c|c|c|}
\hline \multirow{2}{*}{\multicolumn{2}{|c|}{ Показники }} & \multirow{2}{*}{$\begin{array}{l}\text { Одиниці } \\
\text { виміру }\end{array}$} & \multirow{2}{*}{$\begin{array}{l}\text { Хворі на } \\
42 \text { день }\end{array}$} & \multicolumn{3}{|c|}{ Лікування } \\
\hline & & & & 7 днів & 14 днів & 21 день \\
\hline \multicolumn{2}{|c|}{ Гематокритна величина } & $\%$ & $37,17 \pm 7,6$ & $36,83 \pm 1,17$ & $36,83 \pm 0,83$ & $35,83 \pm 0,60$ \\
\hline \multicolumn{2}{|c|}{ Гемоглобін } & г/л & $113,33 \pm 4,51$ & $115,00 \pm 3,81$ & $115,83 \pm 4,17$ & $120,00 \pm 3,44$ \\
\hline \multicolumn{2}{|c|}{ Еритроцити } & Т/л & $5,25 \pm 0,21$ & $5,73 \pm 0,11$ & $5,84 \pm 0,08$ & $5,82 \pm 0,15$ \\
\hline \multicolumn{2}{|c|}{ Тромбоцити } & Г/л & $231,17 \pm 7,60$ & $206,00 \pm 5,16$ & $213,50 \pm 5,99$ & $218,67 \pm 6,95$ \\
\hline \multicolumn{2}{|c|}{ Лейкоцити } & Г/л & $11,13 \pm 0,72$ & $9,57 \pm 0,45$ & $7,35 \pm 0,28 * *$ & $6,95 \pm 0,15^{* *}$ \\
\hline \multirow{2}{*}{ Нейтрофіли } & $\Pi$ & $\%$ & $15,76 \pm 1,29$ & $12,33 \pm 0,80$ & $8,83 \pm 0,60 * * *$ & $6,17 \pm 0,65 * * *$ \\
\hline & $\mathrm{C}$ & $\%$ & $12,17 \pm 1,47$ & $19,01 \pm 1,65^{* *}$ & $21,33 \pm 1,56 * * *$ & $22,00 \pm 0,86^{* * *}$ \\
\hline \multirow{2}{*}{\multicolumn{2}{|c|}{$\begin{array}{c}\text { Еозинофіли } \\
\text { Базофіли }\end{array}$}} & $\%$ & $2,70 \pm 0,73$ & $2,83 \pm 0,54$ & $2,83 \pm 0,79$ & $3,17 \pm 0,48$ \\
\hline & & $\%$ & 0 & 0 & 0 & 0 \\
\hline \multicolumn{2}{|c|}{ Моноцити } & $\%$ & $4,17 \pm 0,83$ & $6,00 \pm 0,58$ & $5,18 \pm 0,65$ & $5,17 \pm 0,75$ \\
\hline \multicolumn{2}{|c|}{ Лімфоцити } & $\%$ & $65,20 \pm 1,48$ & $59,83 \pm 1,04$ & $61,83 \pm 0,79$ & $63,50 \pm 0,67$ \\
\hline \multicolumn{2}{|c|}{ ШOE } & мм/год & $5,67 \pm 0,67$ & $3,67 \pm 0,42$ & $2,00 \pm 0,37 * *$ & $2,17 \pm 0,31 * *$ \\
\hline \multicolumn{2}{|c|}{ Кольоровий показник } & & $0,76 \pm 0,02$ & $0,78 \pm 0,01$ & $0,75 \pm 0,01$ & $0,76 \pm 1,01$ \\
\hline
\end{tabular}

\section{Таблиця 6}

Імунологічні показники крові у мурчаків при лікуванні мікроспорії препаратами “Мікромар" та "Біоглюк" $(\mathrm{M} \pm \mathrm{m}, \mathrm{n}=6)$

\begin{tabular}{cccccc}
\hline \multirow{2}{*}{ Показники } & Одиниці & Хворі на & \multicolumn{3}{c}{ Лікування } \\
\cline { 4 - 6 } & виміру & 42 день & 7 днів & 14 днів & 21 день \\
\hline В-лімфоцити & $\%$ & $22,33 \pm 0,95$ & $24,67 \pm 0,88$ & $26,33 \pm 1,05$ & $24,00 \pm 0,58$ \\
Т-лімфоцити & $\%$ & $53,83 \pm 0,85$ & $53,00 \pm 0,89$ & $50,33 \pm 0,84$ & $51,83 \pm 1,01$ \\
-лімфоцити & $\%$ & $23,84 \pm 1,14$ & $22,33 \pm 1,12$ & $23,34 \pm 1,36$ & $24,17 \pm 1,35$ \\
Натуральні кілери & $\%$ & $19,33 \pm 0,84$ & $19,00 \pm 1,39$ & $18,83 \pm 0,79$ & $17,50 \pm 1,18$ \\
Т-хелпери & $\%$ & $33,33 \pm 0,71$ & $34,33 \pm 0,67$ & $36,50 \pm 0,76$ & $37,33 \pm 0,49$ \\
Т-супресори & $\%$ & $23,00 \pm 1,51$ & $22,17 \pm 0,79$ & $19,33 \pm 0,49$ & $21,00 \pm 0,68$ \\
\hline
\end{tabular}

На 7 добу лікування гістологічна структура шкіри характеризується чіткою візуалізацією рогового, блискучого, зернистого та базального шарів епідермісу (рис. 5). Відсутні потовщення рогового та гіперплазія базального шарів епідермісу, які виникли внаслідок тривалого перебігу мікроспорії (Cooke, 2012). В дермі виявлено розширення кровоносних капілярів та незначні розрихлення, що може вказувати на залишкові запальні реакції, проте запальна інфільтрація відсутня (Scott et al., 2001).

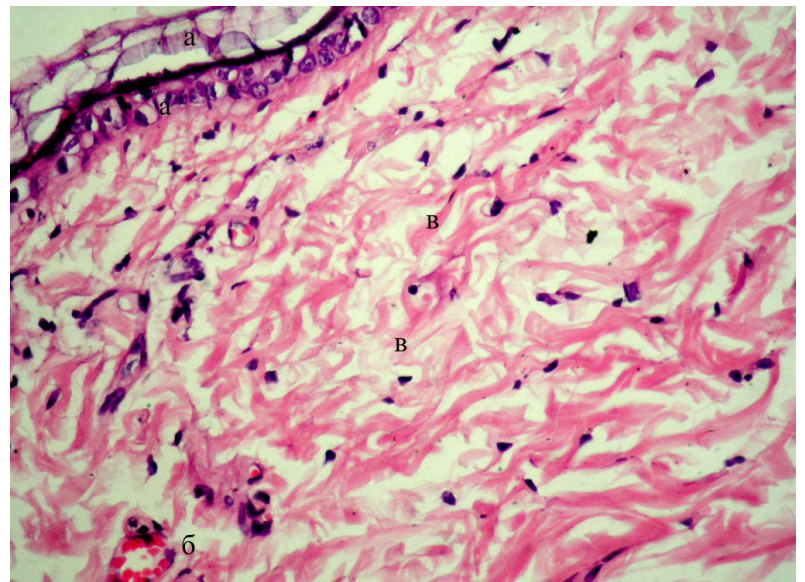

Рис. 5. Гістологічна структура шкіри мурчака на 7 добу лікування: а - епідерміс; б - розширення кровоносних капілярів; в - дерма. Гематоксилін та еозин.

Ок. 10 , об. 10
На 14 добу чітко диференціюються усі шари епідермісу без ознак запалення та дистрофічних змін (рис. 6). Поодинокі еритроцити в товщі дерми є критерієм норми (Cooke, 2012). Дані зміни характерні на завершальних стадіях розрішення запального процесу в шкірі (Sangoi et al., 2009; Martyniv \& Kisera, 2021; Kisera et al., 2021).

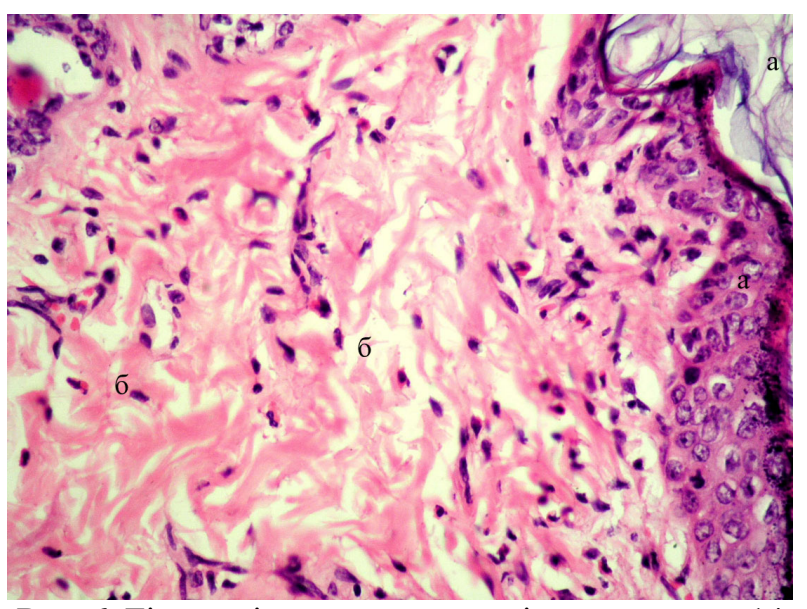

Рис. 6. Гістологічна структура шкіри мурчака на 14 добу лікування: а - епідерміс; б - дерма.

Гематоксилін та еозин. Ок. 10, об. 20 


\section{Висновки}

1. При лікуванні мікроспорії інтраконазолом та клотримазолом проходить гальмування запального процесу, однак спостерігаються ознаки алергізації, які проявляються у вигляді підвищення еозинофілів, зниження тромбоцитів в крові, інфільтрацією товщі шкіри гістіоцитами та еозинофілами.

2. Клотримазол в комбінації 3 вакциною "Вакдерм" знижує ступінь запального процесу, який характеризується зниженням кількості лейкоцитів, паличкоядерних нейтрофілів, збільшенням кількості Т-хелперів, однак зберігається тривала запальна реакція у верхніх шарах епідермісу.

3. Протигрибковий засіб "Мікромар" 3 імуностимулятором "Біоглюк” при лікуванні мікроспорії формують активну імунну відповідь організму, не викликають побічних ефектів i забезпечують швидку регенерацію уражених ділянок шкіри.

Перспективи подальших досліджень. Провести лікування мікроспорії у котів розробленими препаратами “Мікромар" i "Біоглюк” та визначити іiі ефективність.

\section{Відомості про конфлікт інтересів}

Автори стверджують про відсутність конфлікту інтересів.

\section{References}

Bezlushhenko, O. V. (2017). Mikrosporija u koshek. Mir veterinarii, 5, 26-28 (in Russian).

Colombo, S., Scarampella, F., \& Ordeix, L. (2012). Dermatophytosis and urticar eosinophilic/mastocytic dermatitis (urticarial pigmentosa-like dermatitis) in three Devon Rex cats. Journal of Feline Medicine and Surgery, 14(7), 498-502. doi: 10.1177/1098612X12440761.

Cooke, R. A. (2012). Histopathology of some fungal infections. Pathology, 44(1), S47. doi: 10.1016/S00313025(16)32714-3.

de Hoog, G. S., Guarro, J., Gene, J., \& Figueras, M. J. (2000). Atlas of clinical fungi. $2^{\text {nd }}$ edition. Universitet Rovire I Virgili, Reus. Spain.

Dekio, F., Bhatti, T. R., Zhang, S. X., \& Sullivan, K. V. (2015). Positive Impact of Fungal Histopathology on Immunocompromised Pediatric Patients With Histology-Proven Invasive Fungal Infection. American Journal of Clinical Pathology, 144(1), 61-67. doi: 10.1309/AJCPEMVYT88AVFKG.

Gupta, A. K., Alexis, M. E., Raboodee, N. et al. (1997). Itraconazole pulse therapy is effective in the treatment of tinea capitis in children: an open multicenter study. Br. J. Dermatol, 137(2), 251-254. doi: 10.1046/j.1365-2133.1997.18141912.x.

Hamade, L. M. (2016). Rol' sootnoshenija kletochnyh markerov differencirovki CD8+: $\mathrm{CD} 3+\mathrm{v}$ limfocitarnyh infil'tratah kozhi pri gribovidnom mikoze. Clinical medicine/Klinichna medicina, 4(98), 72-74 (in Russian).
Horalskyi, L. P. Khomych, V. T., \& Kononskyi, O. I. (2005). Osnovy histolohichnoi tekhniky i morfofunktsionalni metody doslidzhen u normi ta pry patolohii. Navchalnyi posibnyk. Zhytomyr: Polissia (in Ukrainian).

Kindt, T. J., \& Osborne, B. A. (2006). Kubi, Immunology, $6^{\text {th }}$ ed., W.H. Freeman.

Kisera, Y. V., Martyniv, Y. V., \& Gutyj, B. V. (2021). Dynamics of morphological, immunological and histological changes in microsporia in guinea pigs. Regulatory Mechanisms in Biosystems, 12(2), 206211. doi: $10.15421 / 022129$.

Kisera, Ya. V., Bozhyk, L. Ia., Martyniv, Yu. V., Matviishyn, T. S., \& Pundiak, T. O. (2020). Imunobiolohichni preparaty. Navchalnyi posibnyk $\mathrm{z}$ hryfom LNUVMB imeni S.Z. Gzhytskoho. Lviv: "Spolom" (in Ukrainian).

Kisera, Ya. V., Martyniv, Yu. V., \& Kurylas, L. V. (2020a). Rozchyn "Mikromar" dlia likuvannia dermatofitnykh infektsii. TU U 21.2-00492990024:2020. [Chynnyi vid 2020-12-24] (in Ukrainian).

Kisera, Ya. V., Martyniv, Yu. V., \& Kurylas, L. V. (2020b). Imunostymuliuiuchyi preparat "Biohliuk" TU U 21.2-00492990-025:2020. [Chynnyi vid 202012-24] (in Ukrainian).

Kokhan, I. (1994). Imunolohiia: pidruchnyk imunnosty, serolohii, imunokhimii, imunobiolohii, imunohenetyky. K.: UKSP "Kobza" (in Ukrainian).

Kotsiumbas, I. Ya., Zhyla, M. I., \& Piatnychko, O. M. (2014). Imunotoksykolohichnyi kontrol veterynarnykh preparativ ta kormovykh dobavok: Metodychni rekome-ndatsii. Lviv (in Ukrainian).

Makurina, G. I. (2016). Stan epidermisu ta epidermalnodermalnoho ziednannia shkiry khvorykh na psoriaz i hipertonichnu khvorobu. Patolohiia, 1(36), 73-78. doi: 10.14739/2310-1237.2016.1.70810.

Martyniv, Y. V., \& Kisera, Ya. V. (2021). Hematological, immunological and histological changes in guinea pigs in the treatment of microsporia with drugs "Micromar" and "Biogluk". Ukrainian Journal of Veterinary and Agricultural Sciences, 4(1), 29-32. doi: 10.32718/ujvas4-1.06.

Medvedeva, E. A., Medvedev, Ju. A., Teregulova, G. A., \& Fahretdinova, H. S. (2002). Sovremennye problemy izuchenija zooantroponoznyh dermatomikozov. Problemy medicinskoj mikologii, 4(2), 89 (in Russian).

Medvedeva, T. V., Leina, L. M., Bogomolova, G. A., Chilina, G. A. (2007). Osobennosti immunovospalitel'nogo otveta pri razlichnyh formah mikrosporii $\mathrm{u}$ detej na fone primenenija sistemnyh antimikoticheskih preparatov. Ros. Zhurnal kozhnyh i venericheskih boleznej, 4, 54-57 (in Russian).

Merkulov, G. A. (1969). Kurs patologogistologicheskoj tehniki. L.: Medicina (in Russian).

Novoselov, V. S., \& Novoselov, A. V. (2004). Novye aspekty $\mathrm{V}$ probleme vybora sovremennogo antimikotika. RMZh, 12(18), 47-51 (in Russian).

Peterson, S. (2008). Shkirni khvoroby kotiv. Moskva: Akvarium-Prynt (in Ukrainian). 
Popov, N. N., Lavrov, V. F., \& Soloshenko, Je. N. (2004). Novye gorizonty medicinskoj mikologii. Klinicheskaja immunologija i allergologija. M.:Reinfor, 56-81 (in Russian).

Pototskyi, M. K. (2000). Dermatomikozy. Veterynarna medytsyna Ukrainy, 11, 20 (in Ukrainian).

Ramsey, I. (2007). Small animal formulary. BSAVA. 6th edition. Reprinted with corrections.

Sangoi, A. R., Rogers, W. M., Longacre, T. A., Montoya, J. G., Baron, E. J., \& Banaei, N. (2009). Challenges and pitfalls of morphologic identification of fungal infections in histologic and cytologic specimens: a tenyear retrospective review at a single institution. Am. J. Clin. Pathol., 131(3), 364-375. doi: 10.1309/AJCP99OOOZSNISCZ.
Scott, D. W., Miller, W. H., \& Griffin, C. E. (2001). Fungal skin diseases. In: Muller \& Kirk's small animal dermatology. 6th ed. Philadelphia: WB Saunders, 336-422.

Sergeev, A. Ju. (2003). Farmakoterapija mikozov. Gribkovye infekcii: rukovodstvo dlja vrachej. M., 169-172 (in Russian).

Vavilov, A. M., Samsonov, V. A., Dimant, L. E., \& Vavilov, A. M. (2000). Immunologicheskie issledovanija T-limfocitov v kozhe. Vestn. Dermatol., 4, 4-5 (in Russian).

Vlizlo, V. V., Slivinska, L. H., Maksymovych, I. A., Leno, M. I., \& Halias, V. L. (2014). Laboratorna diahnostyka u veterynarnii medytsyni. Dovidnyk. 2-he vydannia. Lviv (in Ukrainian). 